\title{
PERANAN KOMUNIKASI PEMERINTAHAN DALAM MENINGKATKAN PEMBANGUNAN PADA KAMPUNG INSUMBREI DISTRIK KEPULAUAN ARURI KABUPATEN SUPIORI
}

\author{
Iswahyudi \\ Program Studi Ilmu Pemerintahan, Fakultas Ilmu Sosial dan Ilmu Politik \\ Institut Ilmu Sosial dan Ilmu Politik YAPIS Biak \\ Email : Iswahyudi@iyb.ac.id
}

\begin{abstract}
Abstrak
Komunikasi sangat penting dalam pemerintahan, penelitian ini bertujuan untuk mengetahui peranan komunikasi pemerintahan dalam meningkatkan pembangunan pada Kampung Insumbrei. Penelitian ini bersifat deskriktif kualitatif, teknik pengumpulan data yang digunakan seperti; observasi, wawancara, dan dokumentasi. Metode analisis yang digunakan adalah analisis kualitatif. Hasil penelitian menunjukkan bahwa peran komunikasi pemerintahan pada kampung insumbrei masih belum efektif. Namun hal itu tidak menjadi kendala serius bagi pemerintah kampung dalam membangun dan meningkatkan pembangunan kampung insumbrei. Kepala Kampung memiliki peran penting dalam proses pembangunan di Kampung Insumbrei Distrik Kepulauan Aruri Kabupaten Supiori.
\end{abstract}

Kata kunci: Peranan, Komunikasi Pemerintahan, Pembangunan.

\section{PENDAHULUAN}

Dewasa ini, peran komunikasi disarankan sangat penting terutama dalam pembangunan. Penggunaan komunikasi di sesuaikan dengan fungsi serta tujuan yang diinginkan. Tujuan komunikasi tersebut mancakup menyelesaikan tugas-tugas yang penting bagi kebutuhan hidup serta menciptakan dan memupuk hubugan kerja antara Pemerintahan dan Kepala Kampung demi meningkatkan pembangunan serta kesejaterahan masyarakat kampung. Adapun fungsi yang berkaitan dengan tujuan tersebut sebagai fungsi isi yang melibatkan pertukaran informasi yang diperlukan dan fungsi hubungan yang melibatkan informasi mengenai suatu hubungan dengan orang lain. Menurut Zimmerman et al dalam Mulyana (2001) Melalui komunikasi yang baik antara pemerintah dengan masyarakat akan memberikan manfaat positif untuk meningkatkan kesejahteraan masyarakat. Secara terminologi,komunikasi dapat diartikan sebagai proses penyampaian suatu pernyataan (pesan) oleh sumber kepada penerima baik secara verbal maupun nonverbal yang menimbulkan makna tertentu yang dapat dipahami baik sumber maupun penerima (feedback) melalui saluran tertentu. Kualitas suatu pemerintahan sangat penting bagi kesejahteraan masyarakat.

Komunikasi adalah suatu proses di mana seseorang atau beberapa orang, kelompok, organisasi, dan masyarakat menciptakan, dan menggunakan informasi agar terhubung dengan lingkungan dan orang lain. Pada umumnya, komunikasi dilakukan secara lisan atau verbal yang dapat dimengerti oleh kedua belah pihak. Demikian pentingnya komunikasi maka James Robins dan Barbara Jones (Zamroni, 2009) Menyatakan : Semua organisasi tidak peduli bagaimana bentuk dan tujuannya, ditopang, disatukan, dan melaksanakan fungsinya melalui proses komunikasi. Komunikasi adalah saluran untuk melakukan dan menerima pengaruh, mekanisme perubahan, alat untuk mendorong dan mempertinggi motifasi serta pranata dan 
Jurnal "Gema Kampus" Edisi Vol.12 No.1 Tahun 2017

sarana yang memungkinkan D. Lawrence Kincaid dan Wilbur Schramm dalam Arifin, Anwar (2008) menjelaskan bahwa komunikasi sebagai proses saling membagi atau menggunakan informasi secara bersama dan pertalian antara para peserta dalam proses informasi.

Selain itu komunikasi juga dapat diartikan sebagai proses menghubungi atau mengadakan penghubungan dengan menggunakan bahasa, gerak-gerik, badan, sistem, isyarat, kode, dan lain-lain. Rumusan yang lain dari rumusan di atas dikemukakan oleh William Albig dalam Cangara (2008) dalam bukunya Public Opinion, beliau menulis bahwa komunikasi adalah proses pengoperan lambang-lambang yang berarti diantara individu. Untuk menjelaskan pengertian komunikasi maka beberapa ahli memberikan penjelasan dalam bentuk pengertian komunikasi agar dapat dimegerti dan dipahami, oleh beberapa ahli. Lebih lanjut pengertian komunikasi menurut Carl I. Hovland dalam Arifin (2008), komunikasi adalah proses memungkinkan seseorang (komunikator) menyampaikan rangsangan (biasanya lambang-lambang verbal) untuk mengubah perilaku orang lain (komunikasi).

Pemerintah dalam menyampaikan pesan-pesan pembangunan haruslah mempunyai kredibilitas, daya tarik, kesamaan dalam hal kebutuhan, harapan dan perasaan agar masyarakat dapat dipengaruhi untuk mengikuti keinginan dari pemerintah sehingga pembangunan dapat dilaksanakan.Komunikasi mempunyai sejumlah pengaruh baik terhadap tipe, sasaran,tugas pemerintahan termasuk di dalamnya pemeliharaan hubungan. Tanpa adanya sarana dan fasilitas untuk hubungan komunikasi ke segala arah dalam suatu kegiatan, akan sulit diketahui apa yang sudah dicapai, apa yang akan diraih dan bagaimana kendala dalam pelaksanaan pekerjaan dan komunikasi adalah sumber informasi bagi pimpinan dalam menginformasikan berbagai kebijakan ataupun tentang pembangunan.

\section{Komunikasi}

pemerintahan merupakan komunikasi antara manusia (human communication) yang terjadi dalam konteks organisasi pemerintahan. karena itu komunikasi pemerintahan tidak lepas dari konteks komunikasi organisasi dan juga merupakan bagian dari komunikasi organisasi. Arus penyampaian dan penerimaan pesan dilakukan melalui jaringan yang sifatnya berhubungan dan saling tergantung satu sama lain berdasarkan aturan-aturan formal. Pesan yang disampaikan dan yang diterima bukan saja berupa informasi, melainkan juga penyebaran ide-ide (sharing ideas), intruksi (intruction), atau persaan-perasaan (feelins) berhubungan dengan tindakan dan kebijakan pemerintah (Malone, 1997) .

Namun demikian dalam meningkatkan pembangunan yang berkaitan dengan komunikasi pemerintahan, khususnya yang ada di Kampung Insumbrei ternyata mempunyai kendala, dan sesuai dengan hasil pengamatandi lapangan, Adapun kendala-kendala tersebut yaitu kepala kampung sebagai komunikator kurang dipercaya dalam hal etika menyampaikan tentang proyek pembangunan seringkali pelaksanaanya berbeda jauh dengan apa yang disampaikan, minimnya keterbukaan dan intensitas informasi tentang proyekproyek pembangunan yang masuk dalam kampung dalam arti ketika sementara melaksanakan proyek pembangunan, menurut hasil pengamatan, ternyata tidak ada tranparansi dalam segala hal tentang proyek yang sementara dijalankan tersebut. 
Iswahyudi "Peranan Komunikasi Pemerintahan Dalam Meningkatkan Pembangunan Pada Kampung Insumbrei Distrik Kepulauan Aruri Kabupaten Supiori ”

\section{METODE PENELITIAN}

\section{Lokasi Penelitian}

Penelitian ini dilakukan pada Kantor Kampung Insumbrei Distrik Kepulauan Aruri Kabupaten Supiori, dan untuk mengetahui serta jelas mengenai indikatorindikator yang akan diukur, maka perlu merumuskan fokus penelitian dalam penelitian ini.

\section{Jenis Penelitian}

Dalam penelitian ini, penulis menggunakan penelitian deskriptif kualitatif, yaitu metode dengan prosedur pemecahan masalah yang diselidiki dengan menggambarkan atau melukiskan keadaan subyek atau objek penelitian seseorang, pada saat sekarang berdasarkan fakta-fakta yang tampak atau sebagaimana adanya.

\section{Jenis Dan Sumber Data}

Sumber data dapat diperoleh dari Kepala Kampung Insumbrei Distrik Kepulauan Aruri Kabupaten Supiori, di mana peneliti dapat mengamati, bertanya atau membaca tentang hal-hal yang berkaitan dengan variabel yang diteliti.

\section{Teknik Pengumpulan Data}

Untuk mendapatkan data tersebut, maka diperlukan adanya metode tertentu dalam pengumpulan data. Adapun metode pengumpulan datanya yaitu dengan menggunakan: Studi kepustakaan, observasi,wawancara.

\section{Teknik Analisis Data}

Teknik analisis yang digunakan dalam penelitian ini adalah analisis interatif (Miles dan Huberman 1984). Dalam model analisis ini, tiga komponen analisisnya yaitu redukasi data, sajian data, dan penarikan kesimpulan atau verivikasi, aktivitasnya dilakukan dalam bentuk interaktif dengan proses pengumpulan data sebagai suatu proses yang berlanjut, berulang, dan terusmenerus hingga membentuk sebuah siklus.

\section{HASIL DAN PEMBAHASAN}

\section{Peran Komunikasi Pemerintahan \\ Dalam Meningkatkan Pembangunan Kampung Insumbrei Distrik Kepulauan Aruri Kabupaten Supiori.}

Menurut Bapak Derek Maer selaku Kepala Kampung Insumbrei Mengatakan :

“............Saya selaku kepala kampung insumbrei, yang perlu saya lakukan bagi masyarakat kampung adalah keterbukaan informasi dan transparansi dalam setiap musyawarah kampung, dan itulah yang sering saya lakukan bagi masyarakat. dan pada tahun 2016 saya terpilih sebagai kepala kampung insumbrei dalam masa kepemimpinan saya. Sejauh ini sayasudah menyiapkan beberapa program atau kegiatan yang menjadi dasar atau tujuan dalam membangun sarana dan prasarana di kampung ini sesuai dengan Visi dan Misi saya. sehingga pemerintah kampung insumbrei melakukan beberapa terobosan program yang menjadi program unggulan yang berhasil di laksanakan yaitu : sarana air bersih, pengadaan perahu viber, dan 14 unit motor tempel 15 PK denga penggunaan sumber dana APBK T.A 2016. Adapun kendala atau hambatan yang saya hadapi dalam menjalangkan sistem penyelenggaraan pemerintah kampung ialah kurangnya pendekatan atau kerja sama antara sekretaris kampung dan seluruh staf pemerintah kampung sehingga menghambat proses pembangunan di kampung ini”.

Dari hasil wawancara di atas maka diperoleh informasi bahwa Kepala Kampung 
Insumbrei sudah sukses dalam menjalankan tugas dan fungsi dengan baik. sehingga kepala kampung mencanangkan beberapa program di beberapa bidang yang berbeda. dan itulah yang telah sukses bagi masyarakat kampung insumbrei.

Menurut Ibu Welmina Wawtakeyauw Selaku Masyarakat Kampung Insumbrei Mengatakan :

“..........Menurut saya berbicara soal pembangunan dan penyampaian informasi bagi kami masyarakat pada kampung ini, sejauh ini saya saya rasa semua itu berjalan dengan baik. tetapi salah satu persoalan yang selama ini sering terjadi adalah sebagian masyarakat belum paham tentang bantuan atau pembangunan yang sifatnya berupa swadaya.sehingga banyak masyarakat kurang berpartisipasi dalam hal kerjasama". (Wawancara, 2018)

Dari hasil wawancara di atas maka penulis menyimpulkan bahwa masyarakat merasa sudah puas dengan kinerja pemerintah kampung terutama, kepala kampug dalam hal membangun dan mensejahterakan masyarakat kampung.

\section{B. Competence Kewenangan)}

(Kemampuan/

Untuk meningkatkan pelayanan yang lebih baik, di lingkungan Pemerintahan Kampung Insumbrei ternyata, masih sangat kurang.Hal ini dikarenakan kurangnya kerjasama antara sekretaris kampung dan aparatur kampung dengan kepala kampung sehingga untuk melihat sejauh mana peran dan kinerja pemerintah kampung masih dikatakan belum Competence. Dan disisi lain kepala kampung lebih banyak mempunyai kewenangan dalam hal pengambilan keputusan hal ini disebabkan karena sekretaris kampung dan beberapa staf aparat kampung kurang aktif dalam menjalankan tugas dan fungsinya.

\section{Integritas (Kejujuran)}

Satu diantara kendala paling serius untuk mewujudkan good governance adalah prilaku korup yang menggerogoti hampir setiap lembaga penyelenggara pemerintahan dalam pelayanan publik dari tingkat pusat hingga daerah. Kepala kampung adalah seorang pemimpin yang dipilih oleh masyarakat sendiri untuk menjalankan, meneruskan aspirasi masyarakat. Maka yang menjadi kunci kesuksesan dan keberhasilan pemerintah kampung adalah kejujuran dan keterbukaan kepala kampung dalam hal melayani dan melaporkan. Dan dari hasil wawancara yang peneliti dapat dari masyarakat, ternyata kepala kampung sudah terbuka bagi masyarakat.

\section{Goog Will (Teggang Rasa)}

Bangsa Indonesia terdiri atas berbagai suku, adat istiadat, bahasa, dan agama. Berkat bangsa Indonesia yang berkepribadian Pancasila, perbedaan yang ada tidak menjadi penghalang terwujudnya persatuan dan kesatuan bangsa. Untuk melihat terwujudnya perilaku seorang pemimpin yang sifatnaya tenggang rasa maka, perlu kita melihat kembali sejauh mana ia membangun dan meningkatkan pemabangunan pada kampung tersebut. Karena dengan melihat kesuksesan pemabangunan itu, maka kita bisa mengetahui sejauh mana kepala kampunng meningkatkan Good Will dalam hal pelayanan bagi masyarakat kampung insumbrei. 
Iswahyudi "Peranan Komunikasi Pemerintahan Dalam Meningkatkan Pembangunan Pada Kampung Insumbrei Distrik Kepulauan Aruri Kabupaten Supiori"

Berdasarkan penelitian yang peneliti lakukan melalui wawancara, dan observasi maka dapat di tarik kesimpulan bahwa sejauh ini Kepala Kampung Insumbrei sudah menjalangkan tugas,fungsi dan perannya dengan baik, sehingga kepala kampung mencanangkan beberapa program kerja di beberapa bidang yang berbeda seperti, bidang pembangunan kampung, bidang penyelenggaraan pemerintah kampung, bidang pendidikan, serta bidang pemberdayaan masyarakat kampung. Kepala kampung merupakan pimpinan tertinggi di kampung. Oleh karena itu kepala kampung bertanggung-jawab penuh atas roda pemerintahan yang ada di kampung.

Selain itu kepala kampung juga memiliki peranan penting dalam menjalankan sistem penyelenggaraan pemerintahan kampung dan meningkatkan pembangunan di kampung Namundi kampung insumbreisendiri terdapat beberapa program kerja unggulan guna untuk peningkatan pembangunaan saran dan prasarana yang ada di kampung insumbrei, dalam hal menunjang kegiatan pemberdayaan masyarakat yang sebagian besar di danai dengan dana APBK (anggaran pendapatan dan belanja kampung) maupun dari PROSPEK (Program Strategi Pembangunan Kampung) maka pemerintah kampung insumbrei. Dalam peningkatan pembangunan di kampung Insumbrei ini dimaksudkan untuk membangun sarana prasarana di kampung dan juga meningkatkan kesejahteraan masyarakat kampung Insumbrei.

Pembinaan masyarakat merupakan salah satu unsur yang sangat penting dalam proses pemberdayaan masyarakat, baik bagi perangkat kampung maupun masyarakat. Tujuannya ialah agar perangkat kampug dan masyarakat tahu dan mengerti apa yang harus dikerjakan serta timbul kemauan untuk ikut aktif dalam setiap program atau kegiatan pemerintah. Selain itu, Kepala kampung juga memiliki peran penting dalam membina kehidupan masyarakatnya tidak hanya melalui kegiatan formal tetapi juga melalui kegiatan nonformal. Kepala Kampung harus lebih transparan dan terbuka untuk masyarakat dan bisa mengajak warganya untuk berdialog dan berbincang-bincang secara terbuka.

\section{KESIMPULAN}

Dari hasil pembahasan tersebut diatas, maka penulis dapat mengatakan bahwa ternyata peran komunikasi pemerintahan pada kampung insumbrei masih belum efektif. Namun hal itu tidak menjadi kendala serius bagi pemerintah kampung dalam membangun dan meningkatkan pembangunan kampung insumbrei. Kepala Kampung memiliki peran penting dalam proses pembangunan di Kampung Insumbrei Distrik Kepulauan Aruri Kabupaten Supiori.

\section{DAFTAR PUSTAKA}

Ardianto, Elvinaro dan Bambang Q-Anees. 2007. Filsafat Ilmu Komunikasi. Bandung: Simbiosa Rekatama Media.

Arifin, Anwar. 2011. Political Communication (Philosophy Paradigm - Theory - Purpose Strategy and Political Communication of Indonesia) . Graha Science. Yogyakarta.

Effendy, Onong Uchjana. 2003. Ilmu, Teori dan Filsafat Komunikasi. Bandung : PT. Citra Aditya Bakti. 
Hasan, Ali. 2010. Marketing from Mouth to Mouth. Yogyakarta: Media Pressindo

Hafied Cangara. 2010. Pengantar Ilmu Komunikasi. Kharisma Putra Utama Offset.

Mulyana, Deddy. 2001 . Ilmu Komunikasi: Suatu Pengantar. Bandung: PT Remaja Rosdakarya.

Muhammad, Arni. 2001. Komunikasi Organisasi. Jakarta : Bumi Aksara

Murcholis, " Komunikasi Pemerintahan", Penerbit Jakarta 2005. 